\title{
Impact of the COVID-19 Pandemic on Agri-Food Companies in the Region of Extremadura (Spain)
}

\author{
Beatriz Corchuelo Martínez-Azúa ${ }^{1, *(D)}$, Pedro Eugenio López-Salazar ${ }^{2}$ and Celia Sama-Berrocal $^{1}$ (D) \\ 1 Department of Economy, Faculty of Economics and Business, University of Extremadura, \\ 06006 Badajoz, Spain; celiasamaberrocal@unex.es \\ 2 Department of Business Management and Sociology, Faculty of Economics and Business, \\ University of Extremadura, 06006 Badajoz, Spain; pelopez@unex.es \\ * Correspondence: bcorchue@unex.es; Tel.: +34-924-279520
}

check for updates

Citation: Corchuelo Martínez-Azúa, B.; López-Salazar, P.E.; Sama-Berrocal C. Impact of the COVID-19 Pandemic on Agri-Food Companies in the Region of Extremadura (Spain). Agronomy 2021, 11, 971. https:// doi.org/10.3390/agronomy11050971

Academic Editor: Gabrijel Ondrasek

Received: 30 March 2021

Accepted: 11 May 2021

Published: 13 May 2021

Publisher's Note: MDPI stays neutral with regard to jurisdictional claims in published maps and institutional affiliations.

Copyright: (c) 2021 by the authors. Licensee MDPI, Basel, Switzerland. This article is an open access article distributed under the terms and conditions of the Creative Commons Attribution (CC BY) license (https:// creativecommons.org/licenses/by/ $4.0 /)$.

\begin{abstract}
The coronavirus pandemic is having an economic impact, previously non-existent, on the world economy. The objective of this study is to analyze the impact of COVID-19 on agri-food companies in the region of Extremadura (Spain). A multiple-case study based on in-depth interviews was carried out in the period February 2020-January 2021. The results reveal the existence of negative and positive impacts, both financial (decrease in turnover; decrease/displacement in the demand for products; budget reduction in R\&D projects; increase in certain product sales) and operational (difficulty in marketing activities, lack of staff, stoppage in company activity, and supply problems), depending, principally, on the nature of the products, the changes generated in consumer behavior, and mobility problems. Likewise, changes were observed in processes (search of clients in other markets, increased use of technology in communication and marketing activities, and development of new products) and procedures (reorganization of personnel activities, implementation of new health protocols) in companies to overcome the obstacles imposed by the new situation. In conclusion, the change in surrounding conditions, and the characteristics of the spread of the pandemic, have impacted on the strategies, behavior, processes, dynamics and results of organizations regardless of their size and the nature of their work product or service.
\end{abstract}

Keywords: agri-food companies; COVID-19; multiple-case study; impact; actions

\section{Introduction}

The coronavirus pandemic is having an economic impact, previously non-existent, on the world economy. According to [1], it is a crisis of a historical scale and complexity that is putting to the test health care systems, the fiscal capacity of governments, and the ability of many organizations to cope with and respond to the changes caused by the virus.

In the case of Spain, the strict confinement measures in force from mid-March to early May 2020, as well as restrictions on international tourism, have led to a historic drop in the gross domestic product (GDP) in the second quarter of the year 2020 of $17.8 \%$ quarter-on-quarter (21.5\% interannual), the largest decrease observed since 1995 [2].

Furthermore, the crisis caused by COVID-19 has altered the patterns of food production and consumption worldwide, which has affected the agri-food sector. The agri-food sector encompasses a very heterogeneous set of activities that range from the first transformation of raw materials of animal and vegetable origin to the production of sophisticated products such as functional foods. In the case of Spain, the pandemic situation has highlighted the importance of the agri-food sector as an essential pillar of the economy. During the lockdown months, the entire food chain had to adapt quickly to guarantee the supply of food to the population.

The economic indicators available reveal that the agri-food sector has been one of the least affected by the crisis caused by the pandemic. According to the data provided in the 2020 Agri-food Sector Report [2], the gross added value of the primary sector grew by 3.6\% 
quarter-on-quarter (6.3\% year-on-year) in the second quarter of 2020, with a considerable increase in the consumption of essential goods. The weight of the primary sector over the total economy increased, contributing 3.8\% of the GDP, increasing $1.1 \%$ in relation to 2019.

Within the agri-food sector, the agri-food industry (food, beverages and tobacco) includes 30,730 companies that directly employ more than 436,700 people; these registered an increase of $2.5 \%$ in Social Security affiliation in 2019 [3]. In 2020, the agri-food industry suffered a less marked decline than the manufacturing industry as a whole.

The decrease in food production due to the lockdown and de-escalation in Spain was $9.4 \%$ between April and June 2020, less than the decline in the total manufacturing industry $(26.7 \%)$. According to data provided by the Spanish Federation of Food and Beverage Industries [3], it is expected that the total decrease in production during 2020 could vary between $4 \%$ (optimistic scenario) and $8 \%$ (pessimistic scenario). In the labor sphere, the sector has registered, relatively, less job destruction. Between February and May 2020, it was one of the few sectors that recorded an increase in average affiliation, both in the General Regime (an increase of 5.9\% compared to a decrease of $4.1 \%$ in the national average) and in self-employed workers (an increase of $0.3 \%$ compared to a decrease of $1.1 \%$ in the national average). On the other hand, the use of instruments to contain the destruction of employment (temporary employment regulation files (ERTE in Spanish) and extraordinary allowance for the suspension of activity of the self-employed) has been very low in this sector compared to others [2].

The pandemic has also generated a notable change in the food consumption patterns of Spanish families. During the lockdown in Spain (from mid-March to mid-May 2020) there was a $50 \%$ increase in spending in supermarkets and large food stores. The use of e-commerce also increased by $60 \%$ for the purchase of food, in part to minimize movement and contact among people. Another important effect was a $90 \%$ reduction in spending in restaurants [2]. The drop in international tourism has also had important implications for the demand for food products. The tourism sector has an important and direct influence on the activity of other productive branches in the Spanish economy. In this sense, the agri-food sector acts as a provider of tourist activities. According to the analysis of the input-output tables, for each euro of billing in accommodation and restaurant services, 30 cents come from the agri-food sector [4].

In other words, the drop in tourism is transmitted through the food chain to the suppliers who supply food to restaurants, products that tend to be consumed less frequently at home and that cannot easily find an alternative market. Some of the responses to this situation have been the formation by small producers of alliances to develop online distribution channels and to promote proximity sales, as a way of adapting to this exceptional situation.

Another aspect to highlight is that the agri-food sector is a fundamental pillar of the foreign trade sector of the Spanish economy. In 2019, exports amounted to EUR 50,361 million, $5.9 \%$ more than in 2018 , and represented $17.4 \%$ of total exported goods. Despite the general decline in international trade that has occurred with the pandemic, exports from the Spanish Agri-food sector increased by $4.9 \%$ during the months of June and July 2020 [2]. At the aggregate level, according to the latest provisional 2020 data from the State Tax Administration Agency (AEAT in Spanish) [5], food sector exports in 2020 grew by $6.90 \%$, while imports fell by $1.90 \%$ for the same period.

Focusing on the framework of this study, the agri-food sector is one of the main economic activities of the Autonomous Community of Extremadura (Spain). Extremadura, a region bordering Portugal, is made up of two provinces: Cáceres and Badajoz. This region is extensive in surface $(8.22 \%$ of the country), but sparsely populated (it represents $2.2 \%$ of the total Spanish population). Its 1,059,310 inhabitants (data of July 2020 [6]) are distributed with an average density of 25.7 inhabitants per $\mathrm{km}^{2}$, compared to 92.3 in the rest of the country.

The agricultural and food industry is one of the main economic activities in Extremadura and plays a key role in the regional economy. As a whole, the agri-food sector accounts for 3.4\% of Gross Value Added (GVA) and 4\% of employment. The weight of the 
agri-food industry accounts for over 35\% of industry and 3.96\% of employment [7]. In this sense, the weight of the agricultural sector and its associated industries is substantially greater than the national average. According to data from the National Institute of Statistics (INE in Spanish) [8], in 2020 there were 1382 companies related to the food, beverage and tobacco industries, which represents $2.07 \%$ of the total in the region. Agri-food companies have a weight in the total of the country's industries of $0.89 \%$. This represents in Extremadura more than double what they represent at the national level.

The sector is characterized by dual typologies. Medium-sized industries (mainly meat industries, vegetable and fruit canning industries, manufacturers of vegetable oils and fats, and animal feed producers) coexist with a large number of bakery and confectionery companies. The most important subsectors are the meat industry, which accounted for $27 \%$ of sales in 2010, followed by the manufacture of human food products and the manufacture of beverages [9].

Taking into account this framework, the main objective of the present study is to analyze the impact of COVID-19 on Extremaduran agri-food companies. The following questions are posed: what are the consequences of the pandemic? Additionally, what actions are being carried out? The methodology used to analyze these questions is qualitative by means of a study of multiple cases.

Our study was carried out through in-depth interviews. The responses of those responsible for the management of 15 agri-food companies (cooperatives and non-cooperatives) belonging to different branches of activity and size, as well as an agri-food technology center with great weight in the region, are analyzed. The interviews were carried out from February 2020 to January 2021.

The results of the study reveal that the change in surrounding conditions, as well as the characteristics of the spread of the pandemic, have had an impact on the strategies, behavior, processes, dynamics, and results of organizations regardless of their size and the nature of their product or service.

This work is organized as follows: Section 2 shows, in general, the implications that the pandemic could have in the long term, its effect on the different sectors, the dynamics and the response by organizations and consumers, and a review of recent studies that analyze its effect on the food sector, together with recommendations that are being made to address its negative consequences. The data and the methodology used are presented in Section 3. Based on the responses obtained and, from a transcription of the interviews, the following Section 4 analyzes the impact the pandemic has had and the actions that are being carried out in the different branches of activity in the agri-food industry. The discussion of the results takes place in Section 5. Finally, the main conclusions are presented.

\section{The Dynamics of Responses to the "New Reality"}

Overall, from a macroeconomic point of view, some business analysts have come up with a list of five changes that COVID-19 has brought with it that will have longterm implications [10]. First, the acceleration towards a Digital Economy: in-person contact restrictions are forcing people to interact and work virtually [11-14]. Second, a slowdown in border activity: the pandemic has disrupted trade, travel, and other border activities. This has affected, above all, airlines and tourism [15,16]. Additionally, in some countries, the education sector dependent on international student tuition payments will be affected. Third, a greater role for governments and pressure for reforms: the economic consequences of the crisis imply a greater demand for government services, especially in terms of financial support for the unemployed or companies. It also raises the debate of public versus private healthcare $[17,18]$. Fourth, a greater focus on crisis management and recovery; the situations that people have had to face have made us realize the importance of having a government able to lead the recovery $[19,20]$. Finally, economic pressure; the amount of stimulus packages announced by governments is greater than those invested in the global financial crisis of 2008. 
On the other hand, the impact of the crisis has affected different sectors unequally. Chief Financial Officers (CFOs) in certain sectors such as semiconductors, retail and software are optimistic about the impact of the pandemic on revenues and profits compared to April 2020, while CFOs in other industrial goods industries (such as automotive) are more reserved in their optimism [21].

Ref. [22] studied the segmentation of the impact of COVID-19 based on the nature of the product. They found that the least affected sectors are the real estate and consumer goods market, financial services and food delivery. Other sectors that were affected by the lockdowns, such as the automotive industry, have subsequently been reactivated. Finally, other sectors such as transportation, recreational activities and food services that are directly dependent on the vaccine, in some cases, have not yet recovered their activity to pre-crisis level.

Ref. [23] argued that the different impact according to sectors is determined by the profile of the consumer in the post-pandemic era. Self-confinement, for example, is leading to the growth of certain product categories such as fresh food, home care products, and cable television. Health and wellness have also emerged as priorities for many consumers. Another change in the buying pattern that is being experienced has been determined by a high sense of family and communal relationship, with a desire to buy "local". It is also clear that COVID-19 has accelerated digital behavior in emerging markets.

Another aspect to highlight is the global response that the pandemic has generated in the form of an acceleration of a series of trends that has boosted creativity and innovation in all sectors, seeking solutions to the new conditions of the different markets. As an example, telemedicine, conceived as an essential tool in rural areas, has become an option for general use. Additionally, video conferences and webinars are solutions to social distancing and confinement for companies, education, families and entertainment. According to [24], one of the most significant, complex and wide-ranging trends is the exchange of information, especially the Internet of Things (IoT) in business to consumer and business to business businesses.

In the case of China, although the e-commerce market dates back to the past decade, the ability of digital ecosystems to transform the economy has been proven. The study of [25] shows how COVID-19 is demonstrating the power of the digital ecosystem to respond quickly and creatively to a national crisis. This rapid response is due to operating models that facilitate rapid innovation and diffusion through a wide network of private and public partners. Social networks, e-commerce, and technology companies, such as Alibaba, Meituan-Dianping, Tecent and Baidu, together with their partners in the networks made it possible to develop technology in a short time, thus opening up their ecosystems to new partners.

Another operational change, which affects organizations, relates to the way in which companies are dealing with their relationship with customers and suppliers, limited by the mobility problems of their professionals. In this regard, [26] conducted a survey sent to more than 100 executives about their current experiences in the market and their expectations for the future. The principal finding was that organizations have been forced to switch to teleworking in a short space of time.

Face-to-face meetings, dinners with clients and suppliers, and the entire social element related to these activities have disappeared. Close to $98 \%$ of the companies interviewed provided their sales team with tools to telecommute. Ninety-three percent created a response team to COVID-19, while 50\% did not carry out any strategic planning in relation to the expected impact on prices, volumes and their customer base. For [26], companies should adopt a proactive attitude that allows them to react quickly to threats, a response cabinet (war room) that collects information in real time (or at least daily) with whiteboards displaying key data on volume, prices and customer profit and loss in the most important segments.

These authors recommend, among other actions, to hold weekly sessions to review market trends, to create a strategic response by customer segments, to develop a plan for 
each segment, considering the economic, market and competitive situation, and to plan a recovery strategy [26]. Regarding actions that, in general terms, are being carried out, [27] conducted a survey of $300 \mathrm{CEOs}$ and found that numerous organizations are accelerating their cost reduction objectives, modifying their operating models, and redefining their functional priorities.

Finally, in relation to consumers, their behavior has been altered in several ways: where and how they work, how they spend their free time and what they buy. According to [28], those who are leading the way in changes are the more adventurous generations with less established behaviors: the "millennials" and the " $Z$ " generation. In this sense, the authors report that the crisis has come at a time when massive changes are taking place in the way people interact with the media (media consumption), read books and magazines, watch movies and television, and listen to the radio, in response to the technological changes of recent years. For this reason, the pandemic could be expected to have a more significant impact on consumer behavior than previous crises did.

In relation to consumption, ref. [29] refers to the restoration of "trust" as a major challenge. Entering a restaurant, going to a store, flying, or seeing a live performance all involve high levels of anxiety that will inhibit demand for a long time.

At the level of surveys and recommendations, other studies address the agri-food problem. Ref. [30] developed a prospective study reporting the impact of the pandemic on the Italian agri-food sector during the national shutdown analyzing why and how this unprecedented economic crisis could be a turning point to address the overall sustainability of food systems and agriculture in the framework of the next European Green Deal.

In [31] report, the potential risks faced by the agri-food sectors due to the COVID-19 pandemic are highlighted, the responses and policy actions that the Asian Productivity Organization (APO) member countries are taking to address threats to food security and prevent hunger are outlined.

A study by [32] concluded that the effects of the food system on the spread of disease (and vice versa) should be addressed in future plans to prevent and mitigate large-scale outbreaks. Health policies must recognize the food system as the basis of the health system, just as agri-food policy must recognize the importance of human health (directly and indirectly) in decision-making.

In the [33] report, the impact of COVID-19 on the Egyptian food system was analyzed. A qualitative assessment of the main obstacles was carried out through semi-structured interviews with the main national stakeholders. This evaluation aimed to investigate the following critical areas to guarantee the functioning of the market: supply (availability and access to raw materials, intermediate goods-including packaging-and quality and safe equipment), demand (sustained demand from consumers and the industry), labor (availability and access to skilled labor), production (continuous production and uninterrupted supply), and finance (availability and access to adequate financing mechanisms).

In each area, several bottlenecks were identified. Special attention was paid to food processing and SMEs. Based on the main obstacles detected, recommended interventions have been developed to support the adaptation, recovery and transformation of the agrifood sector in Egypt. Recommended interventions include different types of measures and instruments such as: Information and advice (on, for example, market opportunities, contingency measures, safety and quality); Economic instruments (financial support measures to maintain liquidity and alleviate the financial burden of companies, especially SMEs); Regulations and laws (food safety, or import/export).

Additionally, in [34] a series of recommendations regarding the proposal of business plans aimed at sustaining the agri-food industry are given from the point of view of strategic management such as the planning of commercial scenarios, alternative input supply channels, staggered investment plans in innovation, personnel health and safety practices, and human resources planning in the face of increased demand.

Given how recent the current situation caused by COVID-19 is, it is evident that uncertainty still exists about the effects and problems that the pandemic may cause in a 
sector such as the Agri-food sector. Ref. [35] identifies several dimensions of concern with respect to COVID-19 and agricultural systems, specifying that this list is early and limited and therefore inevitably incomplete.

One of the immediate concerns is the disruption of food systems and the impact on food security [36]. Food distribution channels in almost all countries have been disrupted with strong negative consequences for the most vulnerable. The study by [37] indicates that the supply chain is the sector most affected by the pandemic. In the case of Uzbekistan, a cold supply chain system was introduced to avoid collateral losses of agricultural products.

A second emerging problem concerns the availability of labor in the agrifood sector. There have been significant labor constraints for workers who are critical of agricultural production in some sectors [34].

A third area of concern is the resilience of the agricultural system to COVID-19. It has yet to be determined which systems are resilient and which are not, based on their dependence on external labor, and what technological measures could be taken to reduce dependence on human labor and gain efficiency, and the response of local, regional, national and international agricultural systems to agricultural production losses [34].

Finally, at the national level, two recent reports have analyzed the impact of COVID-19 on the Spanish agri-food sector. The study [38] draws on the opinions of senior executives from 185 companies related to the food and beverage sector. Data on the evolution of turnover, foreign trade, employment and investments of companies in the sector are analyzed. Finally, a reflection on the future of the sector is made. The latest FIAB report [39] analyzes the impact of COVID-19 on the food and beverage sector and establishes measures to increase competitiveness in the sector.

The present study aims to contribute to the still scarce literature existing on the impact of COVID-19 in the agri-food sector, in this case referring to a particular region of Spain.

\section{Methodology and Data}

In this section the methodology and the research design are explained. Following this, the main characteristics of the data are described.

\subsection{Research Design}

To carry out the study, we used a qualitative methodology based on a multiple-case study. In accordance with [40] (p. 57), a qualitative research strategy "imposes a context of discovery and exploration", a circumstance that fits our objective. Additionally, ref. [41] defined the case study as an empirical investigation in which a contemporary phenomenon in its real context, where the limits between the phenomenon and the context are not shown precisely, is investigated, and in it, multiple sources of evidence are used.

According to this author [41], this approach is appropriate because it fosters a broad understanding of the researched issue. There are several categories of case studies. Ref. [41] defines three categories: descriptive, exploratory, and explanatory. For this study, the exploratory approach was adopted.

This methodology is appropriate to the objectives of the study. The study of [42] carried out a literature review analyzing 505 articles and they found that the studies of the agri-food sector are mainly empirical and qualitative studies focusing on one or a few companies (case studies).

An activity previous to our study was the preparation of a report/directory of the agri-food companies of Extremadura. The information required to prepare this report was obtained from the crossing and analysis of diverse databases (National Institute of Statistics, Agri-food Cooperatives of Extremadura and SABI). We considered the population of the Extremaduran Agri-food manufacturing companies in the national classification of economic activities (NCEA) code 10 (Agro-food Industry), 11 (Drinks) and 12 (Tobacco). From these sources of information, the companies were analyzed, and according to the data available at the time, duplicate, extinct or inactive companies, or with erroneous contact information were found. 
Information was extracted from each of them, and completed with details from the web pages. The report contains data from a total of 734 agri-food companies of different legal forms and sizes. At the end of the report, they were categorized based on the classification of the activities they carry out.

Based on this information, the companies contacted to carry out the study were selected. The selection was established based on various criteria such as belonging to branches of activity that develop or produce highly specialized products in the region (e.g., tomato, oil or wine); different sizes and legal forms (e.g., agri-food cooperatives that have great importance in the sector) and are dynamic and innovative organizations. In-depth interviews were conducted with the managers of 15 Extremadura agri-food companies and a technology center with an important weight in the region.

Among the issues raised, those related to the impact of COVID-19 on their activities are analyzed in this study. Specifically, they were asked: What are the consequences of the pandemic? What actions are being carried out? Subsequently, the responses provided by the interviewees were analyzed.

The interviews were recorded and transcribed. To analyze and interpret the information, a coding framework for the interview transcripts was developed.

A previous brief description of the companies and their main characteristics was made (Appendix A). Then, data obtained through the interviews and the transcriptions allowed coding and analysis of the cases according to the aspects to be analyzed.

The transcripts of the interviews were analyzed using specific computer software for research studies based on qualitative methodology. The program used was WebQDA, which allowed to obtain an exploratory analysis of the answers. The main analyzes that were carried out were the coding in both codes and linear information and the study of the frequency of the words most used by the interviewees. Figure 1 summarizes the phases of the research design carried out.

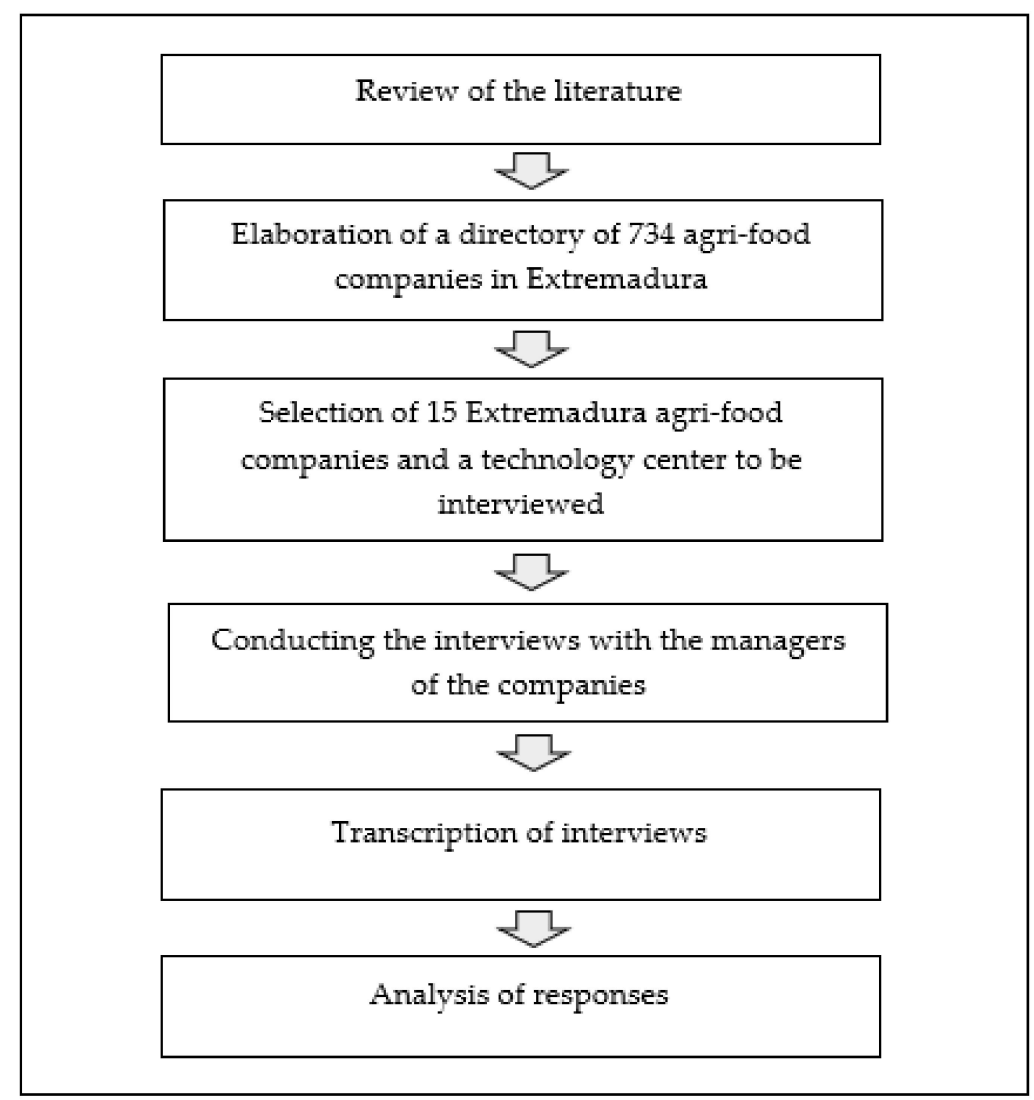

Figure 1. Research design. 
Table 1 shows information from the interviews (companies, person interviewed, gender, modality of the interview, date and length). The numbering of the companies corresponds to the order in which the interviews were carried out.

Table 1. Characteristics of the interviews.

\begin{tabular}{|c|c|c|c|c|c|}
\hline Company & Interviewed & Gender & Modality & Date & Length \\
\hline Company 1 & $\mathrm{CFO}$ & Female & On-site & 28 February 2020 & $1 \mathrm{~h} 50 \mathrm{~m}$ \\
\hline Company 2 & $\mathrm{CEO}^{1}$ & Male & On-site & 13 March 2020 & $1 \mathrm{~h} 15 \mathrm{~m}$ \\
\hline Company 3 & Commercial Director & Female & Video-conference & 8 June 2020 & $2 \mathrm{~h}$ \\
\hline Company 4 & $\mathrm{CEO}$ & Male & Video-conference & 18 June 2020 & $1 \mathrm{~h}$ \\
\hline Company 5 & CEO & Male & Video-conference & 25 June 2020 & $1 \mathrm{~h} 15 \mathrm{~m}$ \\
\hline Company 6 & $\mathrm{CEO}$ & Male & Video-conference & 6 July 2020 & $1 \mathrm{~h} 15 \mathrm{~m}$ \\
\hline Company 7 & Operations Director & Male & Video-conference & 7 July 2020 & $1 \mathrm{~h}$ \\
\hline Company 8 & CEO & Male & Video-conference & 8 July 2020 & $1 \mathrm{~h}$ \\
\hline Company 9 & CEO & Male & Video-conference & 18 July 2020 & $1 \mathrm{~h} 30 \mathrm{~m}$ \\
\hline Company 10 & Department Manager & Male & Video-conference & 20 July 2020 & $50 \mathrm{~m}$ \\
\hline \multirow{2}{*}{ Company 11} & Operations Director & Male & Video-conference & 28 September 2020 & $1 \mathrm{~h}$ \\
\hline & CEO & Male & Video-conference & 6 October 2020 & $1 \mathrm{~h}$ \\
\hline Company 12 & Department Manager & Female & Video-conference & 5 October 2020 & $45 \mathrm{~m}$ \\
\hline Company 13 & CEO & Female & Video-conference & 15 October 2020 & $55 \mathrm{~m}$ \\
\hline Company 14 & CEO & Male & Video-conference & 30 October 2020 & $1 \mathrm{~h} 30 \mathrm{~m}$ \\
\hline Company 15 & CEO & Male & Video-conference & 12 January 2021 & $1 \mathrm{~h} 15 \mathrm{~m}$ \\
\hline Technology center & CEO & Male & Video-conference & 7 October 2020 & $35 \mathrm{~m}$ \\
\hline
\end{tabular}

${ }^{1}$ CEO: Chief Executive Officer.

The first two interviews (companies 1 and 2) were carried out before the Government of Spain decreed the state of alarm and at the company's headquarters. The large amount of news that was already circulating around the world due to the pandemic, especially in early February, led us to include some questions about the impact of the pandemic in the interviews. The lockdown situation from mid-March to early May 2020 paralyzed the interviews, although these were resumed at the beginning of June. Since then, the interviews have been carried out by video-conference using Zoom.

\subsection{Characteristics of the Companies}

This section shows descriptive information of the 15 companies and the technology center that were interviewed. In addition, Table A1 shows the description and other significant information that facilitated knowledge of the selected companies.

Table 2 shows the characteristics of the organizations interviewed (activity, number of employees, billing, whether it is an exporter or not, phase of the supply chain in which the company operates and the market it is targeting). The numbering of the companies corresponds to the order in which the interviews were carried out.

The resulting sample is representative based on the best-selling products in the region, where meat products represent $26.5 \%$ of sales, followed by oils and fats $(17.6 \%)$, and, in third place, fruits and vegetables (16\%). Additionally, highlighted are other animal feed products and wines [43].

With regard to size, only one of the companies has more than 200 workers. Thirty three percent of the companies are micro-companies (they have less than 10 workers), which is also representative of the size of the companies in the industry. Four of the companies interviewed are agri-food cooperatives (companies 4, 6, 13 and 15). The turnover of eight companies is higher than EUR 10,000,000 and only two companies have a turnover of less than EUR 500,000 per year. Moreover, except for one company, all organizations declare that they are exporters. 
Table 2. Characteristics of the organizations interviewed.

\begin{tabular}{|c|c|c|c|c|c|c|}
\hline Company & NCEA $2009^{1}$ & $\begin{array}{l}\text { Number of } \\
\text { Employees }\end{array}$ & Turnover & Export & $\begin{array}{c}\text { Position in Value } \\
\text { Chain }\end{array}$ & $\begin{array}{l}\text { Destination } \\
\text { Channels }\end{array}$ \\
\hline Company 1 & 103 & 600 & $\begin{array}{c}>\text { EUR } \\
10,000,000\end{array}$ & Yes & Transformation & $\begin{array}{c}\text { Other processing } \\
\text { industry }\end{array}$ \\
\hline Company 2 & 104 & 3 & $\begin{array}{l}\text { EUR 1,000,001- } \\
2,000,000\end{array}$ & Yes & $\begin{array}{l}\text { Transformation } \\
\text { Commercialization }\end{array}$ & Retail market \\
\hline Company 3 & 110 & 3 & EUR 0-500,000 & Yes & $\begin{array}{c}\text { Production } \\
\text { Transformation } \\
\text { Commercialization }\end{array}$ & Retail market \\
\hline Company 4 & 110 & 10 & $\begin{array}{c}\text { EUR 1,000,001- } \\
2,000,000\end{array}$ & Yes & $\begin{array}{c}\text { Production } \\
\text { Transformation } \\
\text { Commercialization }\end{array}$ & Horeca channel \\
\hline Company 5 & 108 & 1 & EUR 0-500,000 & No & Commercialization & Retail market \\
\hline Company 6 & 109 & 70 & $\begin{array}{c}>\text { EUR } \\
10,000,000\end{array}$ & Yes & $\begin{array}{c}\text { Production } \\
\text { Transformation } \\
\text { Commercialization }\end{array}$ & $\begin{array}{l}\text { Other processing } \\
\text { industry } \\
\text { Final consumer }\end{array}$ \\
\hline Company 7 & 103 & 60 & $\begin{array}{c}>\text { EUR } \\
10,000,000\end{array}$ & Yes & $\begin{array}{c}\text { Transformation } \\
\text { Commercialization }\end{array}$ & $\begin{array}{c}\text { Horeca channel } \\
\text { Retail market }\end{array}$ \\
\hline Company 8 & 104 & 35 & $\begin{array}{c}>\text { EUR } \\
10,000,000\end{array}$ & Yes & $\begin{array}{l}\text { Transformation } \\
\text { Commercialization }\end{array}$ & $\begin{array}{c}\text { Horeca channel } \\
\text { Retail market }\end{array}$ \\
\hline Company 9 & 101 & 9 & $\begin{array}{c}\text { EUR 500,001- } \\
1,000,000\end{array}$ & Yes & Commercialization & $\begin{array}{l}\text { Horeca channel } \\
\text { Final consumer }\end{array}$ \\
\hline Company 10 & 109 & 10 & $\begin{array}{c}\text { EUR } 6,000,001- \\
10,000,000\end{array}$ & Yes & Commercialization & Final consumer \\
\hline Company 11 & 101 & 66 & $\begin{array}{c}>\text { EUR } \\
10,000,000\end{array}$ & Yes & $\begin{array}{c}\text { Production } \\
\text { Transformation } \\
\text { Commercialization }\end{array}$ & $\begin{array}{l}\text { Horeca channel } \\
\text { Final consumer } \\
\text { Retail market }\end{array}$ \\
\hline Company 12 & 101 & 200 & $\begin{array}{c}>\text { EUR } \\
10,000,000\end{array}$ & Yes & $\begin{array}{c}\text { Transformation } \\
\text { Commercialization }\end{array}$ & $\begin{array}{l}\text { Horeca channel } \\
\text { Retail consumer }\end{array}$ \\
\hline Company 13 & 103 & 110 & $\begin{array}{c}>\text { EUR } \\
10,000,000\end{array}$ & Yes & $\begin{array}{c}\text { Production } \\
\text { Transformation } \\
\text { Commercialization }\end{array}$ & $\begin{array}{c}\text { Horeca channel } \\
\text { Retail market }\end{array}$ \\
\hline Company 14 & 103 & 55 & $\begin{array}{c}>\text { EUR } \\
10,000,000\end{array}$ & Yes & $\begin{array}{c}\text { Production } \\
\text { Transformation }\end{array}$ & $\begin{array}{c}\text { Other processing } \\
\text { industry }\end{array}$ \\
\hline Company 15 & 103 & 6 & $\begin{array}{c}\text { EUR } 6,000,001- \\
10,000,000\end{array}$ & Yes & $\begin{array}{c}\text { Production } \\
\text { Transformation } \\
\text { Commercialization }\end{array}$ & $\begin{array}{l}\text { Horeca channel } \\
\text { Retail market }\end{array}$ \\
\hline $\begin{array}{c}\text { Technology } \\
\text { center }\end{array}$ & 721 & 49 & $>$ EUR 2,000,000 & Yes & $\begin{array}{c}\text { Production } \\
\text { Transformation } \\
\text { Commercialization }\end{array}$ & Final customer \\
\hline
\end{tabular}

${ }^{1}$ NCEA (National Classification of Economic Activities): 101: Processing and preserving of meat and elaboration of meat products; 103: Processing and preserving of fruits and vegetables; 104: Manufacture of vegetable and animal oils and fats; 108: Manufacture of other food products; 109: Manufacture of products for animal feed; 110: Manufacture of beverages; 721: Research and experimental development in natural and technical sciences.

In terms of the role of the companies in the value chain phase, the companies interviewed stand out as being mainly processors, although it is important to highlight that six of the companies and the technological center carry out the entire value chain of their products from production to commercialization. Similarly, the main sales channels where the companies direct their products are the Horeca channel (hotels, restaurants, cafeterias), the retail channel (hypermarkets, supermarkets, shops) and, lastly, direct sales to the end consumer. Only three companies direct their products to other second transformation industries. 


\section{Findings}

A study of the interviews was carried out from which the main results on the impact of COVID-19 were extracted from the transcripts shown in Table A2. The coding of the results through the WebQDA computer software made it possible to determine the words that appeared most frequently. In the research, 20 words were taken as a limit and then the answers were re-coded again based on the results of the word frequencies. Table A3 in Appendix $C$ shows the frequency of the most repeated words. It was determined that the terms "affected" and "actions" had a notable representation in the sample. For this reason, the impact (negative and positive) that the pandemic has had on businesses is analyzed, as well as the actions and main changes that are being carried out to alleviate, in particular, the negative consequences.

Moreover, the main results obtained in the analysis of the responses are summarized in Appendix D. Table A4 shows both the negative and positive impacts of the pandemic, as well as the responses companies have developed to continue with their activities.

\subsection{Negative Impacts}

After the analysis of the responses, we found the following impacts of the pandemic caused by the coronavirus that negatively affected both the financial and operational functioning of the companies.

\subsubsection{Decrease in Sales/Turnover}

The existence of negative results in terms of business volume was revealed in $46 \%$ of the companies analyzed.

Companies 4 (winemaking), 9 (marketer of beef and pork products for hotels, restaurants and direct sales at their facilities), 11 (with entire value chain of Iberian pork meat products), and 14 (first and second transformation of vegetables) revealed that one of the negative effects that the pandemic has caused in their businesses was a decrease in sales. This decline has been more pronounced in companies that produce and market products with most value in the market.

Director of Operations (Company 11): “COVID-19 has had a negative impact and has resulted in a drop in sales. Last year we had a turnover of about 18 million euros. At present, the loss of turnover is about 3 million euros. In other words, we are going to have a $61 \%$ drop in our sales. And also where we are most noticing this drop in sales is in hams, which is the product that contributes volume and margin to the business".

The decrease in turnover was greater in the companies that work mainly in the Horeca channel (hotels, restaurant, and cafeterias), which has remained closed or with limitations since the state of alarm in Spain, in March 2020. This fact was highlighted by the CEO of an important company that produces the first and second transformation of vegetables.

CEO (Company 14): "In the HORECA channel, sales have fallen by 17\%, because the school canteens closed, the restaurants... So we thought that the gains in retail were going to offset these losses, but it has not been the case".

Furthermore, the decrease in turnover was caused not only by changes in consumer behavior, but also produced by the lockdown conditions imposed by the health authorities.

CEO (Company 9): "[ . . . ] taking into account the situation of many citizens, some are in ERTE, others are unemployed, people are afraid and all this leads to a decline in consumption".

Additionally, the encoding of the responses shows that products associated with celebrations and events have experienced a decrease in consumption, which has also caused a decrease in turnover.

CEO (Company 4): "The wine that has suffered the most from the coronavirus crisis is sparkling wine. Unfortunately there were no reasons to celebrate ... ". 


\subsubsection{Displacement in the Demand for Products}

Companies 11 and 12 (meat products) and 13, 15 (vegetable products) highlighted that they experienced a displacement in demand of their products because of COVID-19, which negatively affected them.

The displacement in the demand for products in the market was observed in the responses to the interviews since the state of alarm. As a consequence of the pandemic, the compulsory closure of many establishments of the Horeca channel decreed by the Spanish government has led to an increase in the consumption of products in households.

Head of department (Company 12): "COVID-19 has affected us. In the restaurant area, there has been a lull. Unfortunately, this has been the case and nothing else can be done. On the other hand, we have had an increase in sales in the other area, in filleting and processing. Because in the end, when people were at home, what they consumed were ready meals and they no longer went to restaurants. This has created a very strong demand, which, in fact, in March was a bit overwhelming, because we were waiting for another packing machine to arrive, which fortunately arrived on time because we had to double staff, lines .... In the end, we were all the same, shopping in supermarkets and trying to spend as little time as possible there and people did not stop at the butchers, but preferred ready meals and, in the shortest possible time, to get back home".

Similarly, the manager of a major company producing, processing and marketing garlic in Spain, indicated that in one of its products, directed for sale in hospitality and industry, new technology was incorporated to expand its final product offer. However, they experienced bad results with this product. In contrast, there was a higher demand for household consumption.

CEO (Company 15): "In principle, we almost benefited from the coronavirus situation, since in part the demand for our products is shifting. For example, we have 3 product lines: fresh garlic, peeled garlic clove and garlic paste. In the case of the peeled garlic clove, the final consumer does not use it because it is aimed at hospitality and industry, and the hospitality industry has closed, so its consumption has decreased. It is also true that if consumption in the hospitality industry decreases, household consumption increases, although not in the same proportion, but now the demand for fresh garlic has grown and that of peeled cloves has decreased".

In the same way, in the horticultural branch, following the trend of changes in market consumption, there was a drop in demand for those products aimed solely at catering.

CEO (Company 13): "[ . . ] in berries, we have redcurrant. We have very little of this product. It is commonly consumed and used in desserts; We have had clients who habitually sold it directly to the hospitality industry and this year they have not sold anything".

Finally, it is also worth noting that the economic instability experienced by consumers has affected the demand for higher-value products, causing a shift towards lower-priced substitute products.

Operations Director (Company 11): "[ .. ] consumers, in fear of the situation of economic uncertainty, will always go to those products that have a lower value and this always affects those with higher value ... ". "[ ... ] When there is a crisis situation, like the one we find ourselves in now and the consumer is sensitive to price, the most affected sector will be precisely the one that opts for Iberian and traditional products".

\subsubsection{Difficulty in Marketing Activities}

Companies 2 (olive oil marketer), 5 (marketer of other food products) and 10 (seller of products for animal feed) indicated that they have some kind of difficulty in carrying out marketing activities for their products as a result of the pandemic.

Company 5, a manufacturer of organic patés, had carried out a market study to begin the commercialization of its products in March 2020 in Madrid and Seville; however, the 
state of alarm and subsequent mobility restrictions made the CEO of the company decide to postpone these proceedings.

CFO (Company 5): "I had already done a market study to start carrying out marketing activities in Madrid, Seville ... but after the pandemic started in March we have been inactive. Now at the beginning of May we have started again [ . . ] For now the expectations are good, they are positive, but there is still some uncertainty".

In Company 10 (marketer of products for animal feed), it is essential to carry out faceto-face commercial visits to ranchers and agricultural entrepreneurs, since it allows them to close deals and win new customers. However, due to the restrictions as a consequence of the state of alarm, it was not possible to make $70-80 \%$ of those visits.

Department manager (Company 10): "We have been affected by the coronavirus, especially in terms of visiting our clients. In the end, our sales method in vegetable production is mostly commercial visits to clients". "[ . . ] in April, which is when visits are made to close deals with clients, in the end, up to 70 or $80 \%$ of the visits have been lost".

Promotional activities, attendance at events and fairs have also been affected. In fact, most of them were canceled or have been postponed to later dates. In this sense, the CEO of Company 2 (quality olive oil producer and marketer) indicated that for 3 years he has been attending various international fairs to publicize his product, but this year he will not be able to attend due to the pandemic.

CEO (Company 2): "With the coronavirus we have problems. For example, now in April I was going to Japan and in June to the United States. In June we were going to the Summer Fancy Food in New York, which we have been attending for 3 years, this would be the 4th year. We have also been to Japan in other years, this would also be the 4 th year".

\subsubsection{Slow Down and Budget Reduction in R\&D Projects}

Company 8 (transformer and marketer of vegetable and animal oils and fats) and 11 (realization of the entire value chain of its meat products) stated that their R\&D activities and projects were negatively affected by the situation caused by COVID-19.

CEO (Company 8): "For more than 10 years, RED projects have been developed which have allowed new references to be drawn annually. However, during 2020 the number of projects has reduced and all those that were already underway have slowed down".

CEO (Company 11): "Before the pandemic, we had an investment and development budget of approximately 1,000,000 $€$ intangible assets and we had an investment and development protocol to invest 500,000 $€$ in research and development every year. In fact, in 2019 we invested 800,000 $€$, which was an exceptional investment year. And this year, the pandemic has forced us to cut that budget because the benefits have dropped".

\subsubsection{Lack of Staff (Quarantine)}

To a lesser extent, but not less important, the new situation has also led to problems related to the availability of staff at work. The long periods in quarantine of part of the personnel has caused problems, according to some of the interviewees.

The operations director of Company 7 (transformer and trader of fruit and vegetables) added that the long quarantine periods of 4 people on the team caused problems due to lack of staff.

Operations Director (Company 7): "At the manufacturing and sales level, the truth is that it has not affected us. What we have had are other typical problems. If there was someone who for whatever reason had to carry out the PCR test, then you could not count on that person until they did the test and it was negative twice. So maybe we have lost 2, 3 or 4 people for about 4 weeks, without any being positive in the end". 


\subsubsection{Stoppage or Decrease in Company Activity}

Some companies temporarily paralyzed their activity. Company 1 , leader in the first tomato transformation worldwide, has one of its subsidiaries in China. Nevertheless, the $\mathrm{CFO}$ of this company revealed that this factory in China was forced to suspend production due to the problems and difficulties of transporting since January 2020. In fact, in that country, everything was paralyzed at the beginning of the year 2020 due to the coronavirus pandemic.

CFO (Company 1): "It has affected us, because we have a factory in China and the output of products from China is stopped at the ports. The market in general is stopped in China".

Company 13, which processes, transforms and markets large volumes of fruit and vegetables, introduced, from March 2020, new security protocols to adapt the plant's facilities to the new situation.

CEO (Company 13): "Now, according to our protocols, each line has to enter half an hour after the previous one". This is fine to ensure safety, but it is also causing us to reduce production and activity".

\subsubsection{Supply Problems}

Stoppage of activity, in addition to the closure of international borders, has had an effect on the activity of organizations, either in the movement of products, or in the supply of necessary provisions. Some companies have been forced to redirect both the origin of some of their supplies.

CEO (Company 8: transformer and marketer of olive oil-based products): "[ ... ] Much of the packaging that we use to manufacture our products comes from China. When China closed, they radically stopped manufacturing and an incredible backlog was formed. We had to go to European manufacturers, where an important hold-up also occurred due to the great demand, and to which was added the large shortage of containers produced by the hydroalcoholic gel ..." .

\subsection{Positive Impacts}

However, in addition to the negative consequences that have been previously commented on, it should also be noted that some companies have had consequences derived from COVID-19 with positive impact, generating profits for their companies.

Increase in Production and Sales

In particular, it was noted that in certain activities the demand for some products and, therefore, their production, increased. This trend was experienced mostly in companies that are vegetable producers.

CEO (Company 6: production of cereals, mainly for the production of animal feed): "The agricultural sector did not stop [ ... ] People have continued sowing and harvesting with all security measures [... ] In the case of rice we had a significant increase in cereal production".

CEO (Company 15: production, transformation and commercialization of garlic):

"We also have to say that prices have remained high and demand has increased for our product, dried whole garlic. So, in general, we can say that it has almost benefited us".

In addition, the changing trend in demand for products as a result of the coronavirus pandemic has also led to increased production and sales in products located in the food retail industry. This tendency is observed, especially, in wines sold in supermarkets and in ready meals.

Department head (Company 12: leading company in the transformation of beef products and their commercialization in the Horeca and retail channels): "[ ... ] 
we have certainly had an increase in sales in the other area, in filleting and manufacture. Because in the end, since people were staying at home, they consumed ready meals and they didn't go to restaurants. This has resulted in a strong demand ... ".

\subsection{Other Actions Induced by the Changes}

The consequences derived from COVID-19 have prompted actions to be taken by companies to reduce risks and to adapt their industrial activities to the new situation. Regarding actions induced by the changes, the following were observed.

\subsubsection{Search and Diversification of Clients and Suppliers in Other Markets}

The changes produced in the demand and sale of products have led them to seek new ways of approaching customers, thus increasing their market niche. This is the case of a wine company which, in order to avoid losses in the sales of its products, devised an online tasting service that was certified by a computer engineer.

Commercial Director (Company 3: wine-growing company that enhances all phases of the product value chain): "With the whole issue of the pandemic ... the only ones who have been selling are the supermarkets. People have been consuming a lot of wine, so you have to look for other alternatives. This is how the idea of doing the largest online tasting service so far came about [ ... ] "When the lockdown happened ... I was forced to stop, although my mind did not stop at home [ ... I I had scheduled tastings with clients in restaurants. They were worried, because they had closed. So, I started preparing for an online tasting. But since there were already people doing online tastings, I decided to do the largest online tasting in the world [ ... I In the end 150 people attended the tasting [... ] You have to be very active and know all the tools".

Another of the aforementioned problems was caused by the closure of international borders that forced companies to change suppliers. This problem has been solved by modifying the change of origin of the same. In fact, the CEO of Company 8 added that they had to look for new suppliers in other markets.

CEO (Company 8: transformer and marketer of olive oil-based products): "The closing of the borders caused us supply problems. Much of the packaging that we use to manufacture our products comes from China. So we had problems when that country closed. In fact, in China they suddenly stopped manufacturing. We acted fast and we had to go to European manufacturers".

\subsubsection{Increased Use of Technology in Communication and Marketing Activities}

The problems of communication, mobility, access to end customers, promotion of productive activity and contact with customers and suppliers in general, has led to the introduction, in some cases, and the intensification in others, of the use of technology to make the company function effectively.

Regarding communication activities, the CEOs of companies 6, 15 and the technology center agree that the use of technology in these activities has increased since the state of alarm was decreed in March 2020. They also add that the practicality of these communication tools, the saving of time in the displacements and the reduction in pollution generated on those trips have made tools like Zoom or WhatsApp permanent fixtures.

CEO (Company 6: cooperative leader in the production of cereals and vegetables for sale to other processing industries and end customer at its facilities): "What has come to stay with COVID-19 is [ . . ] having a meeting by video-conference without having to travel. I, who belong to many companies, wasted a lot of time going, coming, apart from the contamination generated by the transfer [ . . ] I already have all the platforms that allow working through video-conference installed. In addition, the meetings are much more participatory, more practical and less time is wasted".

CEO (Company 15: cooperative that produces, transforms and markets garlic): "Digitization is being encouraged. We continue working through WhatsApp, which is a 
very useful tool for making video calls, sending photos ... also, everyone knows it and uses it".

CEO (Technological center): "The coronavirus has also obliged us to get used to this type of meeting and that is in part an organizational change that has come to stay".

In the specific case of Company 13, which produces, transform and markets fruit and vegetables, on which 3500 farmers, members and first-degree cooperatives depend, the pandemic has accelerated the use of online communication platforms. The result has been that all associate members have been given access to the meetings for the first time in 2020 .

CEO (Company 13): "With the situation of the pandemic, Zoom has made it much easier. For example, now we are going to hold a meeting of the Board of all the Governing Boards online. This will allow the rest of the cooperatives to know what the end of the campaign report is and we will allow all the members to connect and not just the administrator of each of the 15 cooperatives as happened before".

In relation to marketing activities, the pandemic has also promoted the creation and modernization of websites and sales platforms of companies.

CEO (Company 6: vegetable products): "Internet sales have also been greatly boosted, and they have come to stay. We sold oil online previously, but we had a rather obsolete payment platform; now we have updated our website and orders can be made on the same page. The coronavirus has forced us to update ourselves [... I In another of the cooperatives in which we have participation, we have created a web page, so the sale of the cheeses is also carried out through the internet".

CEO (Company 11: Iberian pork meat products): "Now we are working a lot on online marketing because we think it is part of the future, especially now with the pandemic".

\subsubsection{Reorganization of Personnel and Activities}

Another of the actions that are being carried out and that is a result of the pandemic is the reorganization of personnel and of workers' activities.

In the case of company 12 (production and commercialization of beef), the stoppage in the Horeca channel caused the demand to shift to filleted products. As a consequence, this company has reorganized the personnel working in the hospitality sector to provide support for the filleting lines.

Department manager (Company 12): "[ . . ] in the catering area, we had a stoppage. [...] However, we have had an increase in sales in the other area, in filleting and processing. [ ...] This has caused a very strong demand ... [ ... ] So, all the staff that we had in the hotel industry have been put on the lines to lend a hand since there has been a lot of demand in that area".

Similarly, the introduction of new hygiene and safety protocols in Company 13's work center (processing and preserving of fruits and vegetables) means that staggered entry of personnel was introduced to minimize contact among employees.

CEO (Company 13): "Perhaps where this situation has affected us the most is at the level of costs at the plant. We have had to invest a lot of money to adapt and implement action protocols for our workers. [ ... I For example, before we had 5 lines and the workers were entering at the same time. Now according to our protocols, each line has to enter half an hour after the previous one".

Activities were also taken to reorganize work at the technology center. In this case, an emergency action plan was drawn up and launched in March 2020. Of the actions reported, of note is the readjustment of activities, which gave the center the chance to set it apart from its competitors.

CEO (Technological center): "Precisely one of the things that we did and that has allowed us to differentiate ourselves from our competitors was to put forward all our public 
projects and to implement an action plan for high-value services that are independent of financing by public entities, because we knew that everything was stopping".

\subsubsection{Implementation of New Health Protocols}

In general, all companies belonging to the food sector work with high standards of quality, hygiene and food safety. However, the crisis caused by the coronavirus has caused some organizations to decide to include new actions and even more demanding protocols. Specifically, in the case of Company 13 (fruit and vegetable processing and preservation) and Company 14, a firm that produces and transforms vegetables for other companies that produce the final product.

CEO (Company 13): produces, transforms and markets large volumes of fruit and vegetables): "[ ... ] We have had to invest a lot of money to adapt and implement action protocols for our workers. Take into account that in the campaign, we can reach 1000 workers and in this situation of health risk we have had to provide many material means such as hydroalcoholic gels, masks, changes of tables in the dining rooms, new temperature controls, spacing the entrance areas of the plant".

CEO (Company 14: producer that carries out the first transformation of vegetables): "In our plant we have had only one positive case and we have protocols that ensure the safety of all our workers. With the positive person in coronavirus we acted fast. In fact, and using the services of an external company, we carried out up to 48 PCRs on all staff members who could have been in contact with that worker [ ... ] In short, as soon as the state of alarm was decreed here, the protocol crisis was activated and implemented right from the beginning".

\subsubsection{Development of New Products}

In the specific case of Company 8 , which manufactures and markets a wide range of products using olive oil as the main raw material, they have taken advantage of the situation of the pandemic to reorient the production of new products. Specifically, they saw the opportunity to produce hydroalcoholic gel and other sanitizing products in November 2019, when one of their franchises located in Barcelona told them that many of their clients were demanding this product and since then, it has been one of their most requested references.

CEO (Company 8): "In cosmetics, seeing the opportunity to make hydroalcoholic gel and sanitizers, we developed a number of products and formats. In November of last year, one of our clients, the franchisee that we have in Barcelona, who receives many Asian, Chinese and Korean clients mainly, noticed that many of those clients were ordering hydroalcoholic gel from him. We have never had this product before and this franchisee requested it form us and now in his 4 stores we sell a lot, because we developed it for him. In the end it has been great for us, because in the last few months we have been selling a lot of hydroalcoholic gel, just because we listened to that customer. And as a result of that, we have developed this same product, but in other formats and even a surface sanitizer, also a sanitizing bath gel ...".

\section{Discussion}

The findings obtained reveal that, although the agri-food industry belongs to an essential and strategic sector in the Extremaduran economy, the coronavirus crisis has also had an impact on this sector, although not to the same extent as on others. This result is in line with what has occurred at the national level in this sector [38,39].

Firstly, our results show a drop in sales and turnover. In line with [38], a significant drop in sales is shown, according to the opinions of the senior managers surveyed. At the national level, and according to the data provided by [39], the drop in turnover for the sector as a whole in the March-August period was around EUR 3680 million, with a 
decrease in turnover in the food branch of around 3\%, compared to a $19 \%$ decline in the beverages subsector.

The most affected agri-food industries, those whose turnover has decreased most, are those whose products are commercialized for use in the Horeca channel, which has remained closed during the lockdown and has also been conditioned by successive months of restrictive measures adopted by the regional government during the "new normality". This sales channel has been one of the most affected at a general level [38,39]. As indicated in [39] for 2020 as a whole, food and beverage sales to the hotel, restaurant and cafeteria (HORECA) sector declined by 50 to $60 \%$, resulting in losses of around EUR 11,700,000,000.

Companies working at some stage of the value chain with products associated with celebrations, such as sparkling wines, have also been negatively affected, as these products have suffered a sharp decline in demand since March 2020.

Similarly, the economic instability experienced by consumers, caused by the pandemic, has also provoked a decline in the consumption of higher value products in the market. From the first quarter of 2020, there has been a shift in demand towards products with a similar positioning and lower price. That is the case of meat companies, in which the most affected were those that manage the entire value chain (from the production of the animal to its commercialization) in the Iberian pork subsector, as they are the most select and highest priced products on the market.

All of these impacts are shown at the national level [38], where a great difference in the impact of COVID-19 on the different links of the value chain has occurred, with a greater drop in the segment of higher-value products, caused by the closure of the Horeca channel. There has been a decline in high-margin formats (those for individual consumption) as opposed to Multipacks and the family format. Products such as caviar, quality wines and cheeses have suffered particularly from the restrictions imposed on bars and restaurants. However, part of this interrupted or sharply reduced consumption in the on-trade has been replaced by a greater demand for products for home consumption.

Marketing activities, the development of R\&D projects, and the provision of raw materials by suppliers have also been affected by the negative consequences of COVID-19. The mobility restrictions and border closures as measures to contain the spread of the coronavirus have hampered the marketing activities of all companies, regardless of the area of activity or the stage of the value chain in which they operate. Another effect that the pandemic has also brought is increased use of the online channel. In [38], it is indicated that it is in the larger cities where this type of commerce has grown the most, reaching $5 \%$ during some periods.

Although R\&D activities and projects have been reduced compared to previous years, these activities have been the least affected, as shown in the results; in fact, some companies have continued to develop R\&D and innovation projects and investments [44].

Conversely, the companies that have been less affected are those that have diversified their sales channels. The diversification of sales channels has given them a competitive advantage, as they have compensated for the fall in sales in the Horeca channel with the increase in demand for other products associated with home consumption and which are located in the retail sales channel. A similar result is found in [38,39].

Additionally, those companies which are producing and carrying out the first processing of certain cereals and agricultural crops have experienced an increase in demand for their products, in response to which companies have taken measures to increase their production.

Based on the consequences that have arisen since the state of emergency was declared in Spain, the companies interviewed have carried out a series of actions. The analysis of the interviewees' responses has allowed us to identify these actions, such as, for example, the search for and diversification of clients and suppliers. In the case of agri-food companies producing and processing food, the results obtained show that the main actions they have undertaken are the reorganization of activities and of staff, and the introduction of additional hygiene protocols in their workplaces to ensure the safety of their workers and 
to prevent infections. In addition, most of the interviewees highlight that since March 2020 they have increased the use of technology in their activities; there is an increased use of technology in marketing activities through the creation or redesign of websites and online shops, and the use of technological tools for the development of communication activities is also on the increase.

According to [34] and given the impact that COVID-19 has generated and the uncertain future of the pandemic, the agri-food industry must modify its business models. In this sense, in this report a series of recommendations on the proposed business plans aimed at sustaining the agri-food industry have been established, which have been identified in the actions carried out by the agri-food companies of Extremadura. On the one hand, from the point of view of strategic management, there are actions aimed at implementing deviations from the business approach, by planning commercial scenarios (Companies 3 and 5), alternative input supply channels (Company 12), staggered investment innovation plans (Company 11), review of personnel health and safety practices (Company 7) and human resources planning in the face of increased demand (Company 11). In the specific case of small companies, the importance of managing the cash outflow and inflow from acquisition to sale to ensure survival should be highlighted as the main recommendation. However, in the present research, no company from the sample matches this recommendation.

\section{Conclusions}

It is clear that the health crisis caused by COVID-19 is having important consequences on the economy as a whole and on the sectors and branches of global economic activity. This study analyzes the impact of the pandemic in the agri-food sector, with special reference to Extremadura (Spain). It was carried out through a qualitative study of in-depth interviews with managers of 15 selected agri-food companies, as well as an agri-food technological center.

Based on the analysis of the responses provided, the impact of COVID-19 in this sector was studied. COVID-19 is having negative consequences (decrease in turnover, reduction and displacement of demand, difficulties in commercial activities, slow down and limitation of budgets allocated to $R \& D$ and innovation, stoppages or decrease in business activity and supply problems). However, positive consequences have also been detected in some branches of activity, such as an increase in production. As a result, these consequences have accelerated the actions carried out to mitigate their effects. Specifically, some of the actions taken are the search and diversification of customers and suppliers in other markets, increased use of technologies in communication and marketing activities, the reorganization of personnel and activities, the development of new products and the implementation of new health protocols.

Finally, and as the main conclusion, the change in surrounding conditions, together with the characteristics of the spread of the pandemic, have had an impact on strategies, behavior, processes, dynamics and results of organizations regardless of their size and the nature of their product or service. Although this was to be expected, the resilience shown by the agri-food sector is notable, despite the general destruction of employment and productivity that the pandemic has caused in Spain. This result is consistent with that indicated in the [27] report, in that Extremaduran agri-food companies are experiencing changes in the operating models and functional priorities in their businesses. There are certain aspects that, even though measures were already being adopted to put them into practice, have accelerated, such as virtual communication, teleworking and digitization, this latter aspect being essential with regard to gaining competitiveness.

This study has two important implications. On the one hand, for the managers of agri-food companies through the actions and changes that are being carried out in an accelerated way to alleviate the effects of the crisis in the sector, not only on the strategy and technique of production and supplier relationship, but also as a result of the change in consumer behavior. In this sense, the openness of companies to innovation and the search and diversification of sales and distribution channels is an important aspect to be taken 
into account. On the other hand, it is also intended to be a guide for public administrations, especially the regional government, for the adoption of measures that could mitigate the negative consequences in the sector and help to overcome the changes that are necessary being adopted and will continue to be adopted. These measures are aimed at developing policies that help prevent and mitigate outbreaks. The importance of the food system for people's health is recognized in health policies which support food safety and quality [33]. Agricultural policies must establish measures that guarantee the overall sustainability of food and agricultural systems [30,32], as well as supply and production [33]. Finally, the agri-food sector can contribute to job creation, for which it is necessary to promote training from the point of view of education policies that provide information and advice and promote innovation in companies [45].

Our research has some limitations. As the case study methodology recommends, interviews should be conducted at the headquarters of the companies to promote the exchange of information between both parties. However, restrictions in mobility as a consequence of the state of alarm decreed by the Spanish Government in March meant that only the first two interviews were carried out at the companies' headquarters and the rest were done by video-conferences. Furthermore, another limitation is the scarce literature on the effect of COVID-19 in the agri-food sector in particular and its comparison with other countries and regions, which does not allow us to make comparisons with other countries and regions, although this is also the main novelty of our research. Future lines of research will focus on expanding the sample of companies. It is also intended to accompany the qualitative study with a quantitative one. Finally, it would be of interest to explore and expand the obtained effects of these positive and negative impacts on other variables, especially regarding sustainability (SDG 11), responsible consumption and production (SDG 12) and entrepreneurship, innovation and value creation (SDG 9) in line with the United Nations sustainable Development Goals (SDG) [46].

Author Contributions: Conceptualization, B.C.M.-A., P.E.L.-S. and C.S.-B.; methodology, B.C.M.-A., P.E.L.-S. and C.S.-B.; formal analysis, B.C.M.-A., P.E.L.-S. and C.S.-B.; investigation, B.C.M.-A., P.E.L.S. and C.S.-B.; data curation, B.C.M.-A., P.E.L.-S. and C.S.-B.; writing-original draft preparation, B.C.M.-A. and C.S.-B.; writing-review and editing, B.C.M.-A. and C.S.-B.; visualization, B.C.M.-A. and C.S.-B.; supervision, B.C.M.-A.; project administration, B.C.M.-A.; funding acquisition, B.C.M.-A. All authors have read and agreed to the published version of the manuscript.

Funding: This research was funded by the Junta de Extremadura (Spain) and European Regional Development Fund grant number IB18040 and GR18058 (SEJ022-Research Group INVE).

Informed Consent Statement: Informed consent was obtained from all key informants involved in the study.

Data Availability Statement: Not applicable.

Acknowledgments: We express great thanks to all key informants for providing the information. We are grateful to James $\mathrm{McCue}$ for assistance in language editing. Finally, we express acknowledge to three anonymous reviewers whose comments and suggestions have been very useful to improve the paper.

Conflicts of Interest: The authors declare no conflict of interest. 


\section{Appendix A}

Table A1. Description of the companies.

\section{COMPANY 1: Processing and preserving of fruits and vegetables}

Company 1 is a second-generation family business. It was founded in 1976. It currently ranks second in the production of tomato powder worldwide. It is a primary producer, whose main clients are multinational food processors. Since 2014, it has begun a process of expansion which involves direct investment and location in countries with important markets, such as China and the United States (California). In Spain, it has also multiplied its production infrastructures, to achieve proximity to its suppliers and to have greater stability in the supplies of raw materials, since they are sometimes affected by climatic changes. The group resulting from the expansion has an average of 600 workers, but at the height of the season they can reach 1600 . It produces a total of 300 million kilos of tomatoes, which is equivalent to $25 \%$ of the tomatoes of the Iberian Peninsula and $3.5 \%$ of the world production.

\section{COMPANY 2: Manufacture of vegetable and animal oils and fats}

Company 2 is a small company with five workers that was founded in 2015 and belongs to the subsector of the manufacture of extra olive oil, its subsequent packaging, and marketing. Its facilities are modern and they have their own olive groves. In addition, its product portfolio also includes sherry vinegar, fragrant cooking wine, as well as aceiterol (an active ingredient in cosmetics), and olive leaf tea. They are oil exporters, with a presence of their brand in Japan, Mexico, the United States and Germany, among other countries.

\section{COMPANY 3: Manufacture of beverages}

Company 3 is a family winery that was born in 2003 as a consequence of continuing with the family trajectory of winemakers. The goal is to make a high quality own brand of bottled wines. It has a limited range of products, among which are red and white organic wines. They invest in an $R \& D$ project. In addition, the company has recently started exporting to clients in the United Kingdom, Belgium and Portugal.

\section{COMPANY 4: Manufacture of beverages}

Company 4 is an agrarian transformation society (SAT in Spanish). It was founded in 1982, and it is located in Almendralejo (Badajoz). It is a family business, with a tradition of more than five generations in the cultivation and production of wines. Ten employees work in the winery. The wines they make are red, white and semi-sweet. In recent years, they have begun to make sparkling wine (cava in Spanish), and for this, they built a second winery in 2019. The organization has also diversified its activities and has a restaurant within the winery's facilities, they offer tastings, pairings, events and guided tours. They market their products nationally and internationally to markets such as the United States or Japan.

\section{COMPANY 5: Manufacture of other food products}

Company 5 is a young organization that was founded in 2019 with its headquarters in Los Santos de Maimona (Badajoz). It was established by an individual entrepreneur and its industrial activity is the production of organic and vegan patés. For the elaboration of its products, it subcontracts production to another regional company which is a leader in the manufacture of conventional patés. The company has only one employee, the owner. It markets its products through online sales, distributors, in gourmet stores and other specialized stores. The turnover is less than EUR 500,000.

\section{COMPANY 6: Manufacture of products for animal feed}

Company 6 is an agrarian transformation society (SAT), located in Don Benito (Badajoz). It was founded in 1985 and its main activity is the manufacture of products for animal feed, although in recent years it has diversified its activity, working with products such as tomato, oil, rice, compound feed, seeds, fertilizers and phytosanitary products. They have five production centers and are also shareholders of several agri-livestock companies in the region. They market their products regionally and nationally, and also in Italy and Portugal. It is a benchmark company within the agrarian cooperatives in Extremadura and Spain. The Spanish Business Confederation of the Social Economy (CEPES in Spanish), in its annual report, ranks it no. 67 out of the total of 722 national agri-food cooperatives, with EUR 68,000,000 in turnover and 70 employees. 
Table A1. Cont.

COMPANY 7: Processing and preserving of fruits and vegetables

Company 7 is the subsidiary of a Portuguese multinational leader in the production and commercialization of vegetable oils, biofuels, soaps and olives. It began its activity in 2008, when the Portuguese group to which it belongs bought an old olive processing factory in Plasencia (Cáceres). It currently has 60 employees who work in the dressing of green and black table olives. They market their products in a wide variety of countries through their own brands and distribution, providing them with a turnover of more than EUR 30,000,000 per year.

COMPANY 8: Manufacture of vegetable and animal oils and fats

The origins of Company 8 date back to 1932, although it was not until 1996 when the company was established as a limited company for the fourth generation of the family. They manufacture and market products made with extra virgin olive oil that is divided into: olive oil, gourmet products and cosmetics. The headquarters and activity center are located in Plasencia, where they have 35 workers and where the central offices, industrial warehouses and an oil library are located. The organization also has two of its own stores and a franchise network made up of more than 39 stores spread across Spain and other European and international countries. They market their products to individuals, gourmet shops, other delicatessens and businessmen belonging to the Horeca channel. They do not sell in large stores or do private labels for any supermarkets. Their turnover amounts to EUR 18,000,000, they pack more than 6,000,000 L of olive oil a year and they export to more than 35 countries. Company 8 is considered one of the 10 most important Spanish companies in this market segment.

COMPANY 9: Processing and preserving of meat and elaboration of meat products

Company 9 is a limited company of family origin located in Fregenal de la Sierra (Badajoz), made up of three founding partners and a total of nine employees. Created in 2012 after the dissolution of another company in 2008 that fell into bankruptcy, it is a producer, processor and marketer of Iberian cattle and pigs raised in extensive systems. They work the entire value chain of their products, with the exception of slaughter. They carry out national and international commercial activity in different markets, such as Europe and Latin America or Asia. Its clients are final consumers, other companies and the hospitality sector, which provide it with a turnover of close to EUR 1,000,000.

COMPANY 10: Manufacture of products for animal feed

Company 10 is a limited company created in 2013 and of family origin that is located in Badajoz. They function mainly as distributors of agricultural products that have been developed and patented together with their "partners" in France. Its main objective is to advise and commercialize agricultural products nationally and in Portugal. In 2020, they reached a turnover of more than EUR 6,000,000 and have a total of 10 employees.

COMPANY 11: Processing and preserving of meat and elaboration of meat products

Company 11 is a limited company established in 1995 that manufactures meat products from acorn-fed Iberian pigs and controls the entire value chain. It is made up of 75 livestock partners from Extremadura and Andalusia and another 16 collaborators in the Portuguese Alentejo. The company is a leader in the production of pure Iberian hams in Extremadura. Currently, they market their products in more than 25 countries, in particular, Canada, Japan, the United Kingdom and France.

COMPANY 12: Processing and preserving of meat and elaboration of meat products

Company 12 was established in 1998 as a public limited company by two partners with extensive professional and family careers in the meat sector. The company is the leader in Spain in the production of meat and beef products. It is currently made up of 400 employees distributed in two locations, one in Madrid and the other in Almaraz (Cáceres), made up of 200 workers. This company has strategically located the slaughterhouse and cutting plants in Extremadura, since Extremadura is the second Community in the census of cattle breeders. The company has clients in large distribution, export, retail and wholesale markets. They invoice more than EUR $200,000,000$ annually. In addition, they sell their products nationally $(70 \%)$ and the rest is exported, mainly to Europe, although they have also worked in Africa and Asia. 
Table A1. Cont.

\section{COMPANY 13: Processing and preserving of fruits and vegetables}

Company 13 is a second-degree cooperative that integrates 16 other first-degree cooperatives from the northern area of Extremadura. This company markets products from its member cooperatives (cherries, chestnuts, dried figs, plums and berries), it markets other processed products in which it subcontracts its production and it carries out transformation in the distillery and oil mill activities. It was established in 1986 in Valdeastillas (Cáceres) and currently produces more than 20,000 tons of products; The company works with 3500 farmers and has 110 permanent employees 900 , more of which are added during the high seasons. This company is a leader in the retail channel, especially with its flagship product, the cherry. Its clients are large hypermarket and supermarket chains. They also carry out foreign trade, exporting 50-60\% of their production, mainly to Europe, although they also work with non-European countries, such as the United Arab Emirates and Hong Kong.

\section{COMPANY 14: Processing and preserving of fruits and vegetables}

Company 14 is a limited company located in Badajoz that has a total of 55 permanent workers, reaching 120 with discontinued workers. This joint venture was established in 2010 by two Belgian multinational groups with a $50 \%$ stake each. It is dedicated to the first and second transformation of vegetable products that are finally deep-frozen (peppers, courgettes, aubergines, potatoes, sweet potatoes, etc.). They work with more than 170 references that are packed in bulk and in different quantities, although the final part of production, mixing and packaging is carried out in other production plants of multinational groups. They market their products in the Horeca, retail and large industrial channels, billing more than EUR 32,000,000 per year.

\section{COMPANY 15: Processing and preserving of fruits and vegetables}

Company 15 is an Extremaduran cooperative company that integrates 45 partners and is dedicated to the transformation and commercialization of fresh whole garlic, paste and peeled garlic cloves. It was established in 2003 and is located in Aceuchal (Badajoz), where six permanent employees and 74 temporary employees work. It is a leading company in the marketing of garlic nationally and internationally. It produces more than 5000 tons of garlic per year and invoices between EUR 6,000,000 and EUR 10,000,0000 per year. Since 2012, they have marketed their products in Brazil, North America, Canada and European countries. As a result, they have experienced continuous growth reaching $10 \%$ in 2020.

\section{TECHNOLOGICAL CENTER}

This is a leading private agri-food technology center in terms of innovation located in Badajoz and established in 2001. Its business activity is based on supporting companies in the agri-food sector by offering research, development, innovation and training services to contribute to the competitive development of regional, national and international companies. Its technological center is very innovative, in fact, it has several pilot plants, experimental farms, laboratories, kitchens, tasting rooms and other facilities for process control, where a total of 49 employees are working.

\section{Appendix B}

Table A2. Impact of COVID-19 on the companies interviewed.

\section{COMPANY 1}

CFO: "It has affected us. Because we have a factory in China and the output of products from China is stopped at the ports. The market in general has stopped in China".

CFO: "Luckily we have a very residual business there. To give you an idea, this factory in Villafranco del Guadiana makes 300 million kilos, we remember that, in total, we have 11 production centers and our factory in China makes 50 million. And well, in China now everything is stopped and now in Europe we need to wait to see what happens".

\section{COMPANY 2}

CEO: "Until the coronavirus happened, we exported to Taiwan, Japan, Canada, the United States and then in Europe, in countries like Germany". 
Table A2. Cont.

\section{COMPANY 2}

CEO: "With the coronavirus we have problems. For example, now in April I was going to Japan and in June to the United States. In June we were going to the Summer Fancy Food in New York, which we have been attending for 3 years, this would be the 4 th year. We have also been to Japan in other years, this would also be the 4th year".

\section{COMPANY 3}

Commercial Director: "With the whole issue of the pandemic ... the only ones who have been selling are the supermarkets. People have been consuming a lot of wine, so you have to look for other alternatives. This is how the idea of doing the largest online tasting service so far came about".

Commercial Director: "When the lockdown happened ... I was forced to stop, although my mind did not stop at home [... I I had scheduled tastings with clients in restaurants. They were worried, because they had closed. So, I started preparing for an online tasting. But since there were already people doing online tastings, I decided to do the largest online tasting in the world [ ... I In the end 150 people attended the tasting [ ... ] You have to be very active and know all the tools".

\section{COMPANY 4}

CEO: "The wine that has suffered the most from this coronavirus crisis is sparkling wine. Unfortunately, there are no reasons to celebrate... I have a meeting this afternoon with the governing board and one of the topics that we are going to discuss is the harvest, to see how we are going to organize it and it is not clear how prices will evolve. Farmers are concerned about prices".

\section{COMPANY 5}

CEO: "I had already done a market study to start entering Madrid, Seville ... but then what happened happened and the truth is that during COVID-19 we have been inactive. Now at the beginning of May we have started again [ ... ] For now the expectations are good, they are positive, but there is still some uncertainty".

\section{COMPANY 6}

CEO: "The agricultural sector did not stop [ . . . ] People have continued sowing and harvesting with all security measures [ ... ] In the case of rice we had a significant increase in cereal production".

CEO: "What has come to stay with COVID-19 is [ . . ] having a meeting by video-conference without having to travel. I, who belong to many companies, wasted a lot of time going, coming, apart from the contamination generated by the transfer [ ... I I already have all the platforms that allow working through video-conference installed. In addition, the meetings are much more participatory, more practical and less time is wasted".

CEO: "Internet sales have also been greatly boosted, and they have come to stay. We sold oil online previously, but we had a rather obsolete payment platform; now we have updated our website and orders can be made on the same page. The coronavirus has forced us to update ourselves [... I In another of the cooperatives in which we have participation, we have created a web page, so the sale of the cheeses is also carried out through the internet".

CEO: "COVID-19 has led us to do things that we already did, but we did them in a half-hearted way; well, now we do them $100 \%$ and as I said, they have come to stay, such as virtual meetings and Internet sales".

CEO: "With the coronavirus, I believe that the most important thing is yet to come, that is, the economic recession that comes with the fall of the economy will mean that there is less consumption. In our case, as a primary sector it will be one of the things that will decrease the least [ . . . ]".

CEO: "The situation we have experienced has to open the eyes of governments, because certain sectors cannot depend on third countries [ . . . ] We cannot hope that food will be provided by the United States or Brazil, but rather that governments have to have a series of issues that as a society are essential. In food we cannot dismantle our livestock and agriculture because there are others that also do so, because at some point they may stop serving you or set prices, and sectors as strategic as the primary sector cannot be dismantled".

\section{COMPANY 7}

Director of operations: "It has forced us to adjust our protocols [ . . ] because being a food company, the hygienic protocols are high and we have had to increase them even more and try not to have so much contact between the employees". 
Table A2. Cont.

\section{COMPANY 7}

Director of operations: "At the manufacturing and sales level, the truth is that it has not affected us. What we have had are other typical problems. If there was someone who for whatever reason had to carry out the PCR test, then you could not count on that person until they did the test and it was negative twice. So maybe we have lost 2, 3 or 4 people for about 4 weeks, without any being positive in the end".

\section{COMPANY 8}

CEO: "Export has not affected us too much. When the Spanish market stopped ... well, we sell a lot in Asia, it is one of our main markets with countries like Korea and China, especially in cosmetics. So both Korea and China were inactive in January or February, then they began to recover and in March we were already taking orders for those countries. And after these two markets, we also sell a lot in Europe, especially the central and northern part, which has not been affected as much as in Spain, France and Italy. So, we have continued to function".

CEO: "The stores, our franchises, in the Spanish market have been closed for a while".

CEO: "Where the virus situation has affected us is in the development of new products".

CEO: "[ ... ] Much of the packaging that we use to manufacture our products comes from China. When China closed, they radically stopped manufacturing and an incredible backlog was formed. We had to go to European manufacturers, where an important hold-up also occurred due to the great demand, and to which was added the large shortage of containers produced by the hydroalcoholic gel ....".

CEO: "The closing of the borders caused us supply problems. Much of the packaging that we use to manufacture our products comes from China. So, we had problems when that country closed. In fact, in China they suddenly stopped manufacturing. We acted fast and we had to go to European manufacturers".

CEO: "They have been a difficult few months and they have slowed us down a lot for the development of new products".

CEO: "Sales have also dropped a lot".

CEO: "In cosmetics, seeing the opportunity to make hydroalcoholic gel and sanitizers, we developed a number of products and formats. In November of last year, one of our clients, the franchisee that we have in Barcelona, who receives many Asian, Chinese and Korean clients mainly, noticed that many of those clients were ordering hydroalcoholic gel from him. We have never had this product before and this franchisee requested it form us and now in his 4 stores we sell a lot, because we developed it for him. In the end it has been great for us, because in the last few months we have been selling a lot of hydroalcoholic gel, just because we listened to that customer. And as a result of that, we have developed this same product, but in other formats and even a surface sanitizer, also a sanitizing bath gel ..." ".

CEO: "With the coronavirus we have stopped doing some things, but we have started to develop others".

\section{COMPANY 9}

CEO: "The coronavirus has affected us negatively and significantly. It has affected us more because now it has also been the bubble that has existed in the pork sector worldwide, in countries like China, Vietnam or Japan, which have been depending a lot on Spanish products, German products, Chilean products; American products ... because they have had barriers with tariffs and boycotts that have been made between capitalist countries worldwide... So, well, what we have seen is that there has been an important bubble and right now you can say that there is an excess of production and that has affected".

CEO: "With the current situation, there are companies that are not from the primary sector like us, for example, slaughter companies and they have been able to do an ERTE. On the other hand, we have not been able to do any ERTEs because we are cataloged within the primary sector and they have not let us do it. So, we have had to work things in other ways".

CEO: "Our turnover does not reach a million euros, although it is true that it is increasing, although COVID-19 has slowed down".

CEO: "We have end customers, we have companies that consume us, we have the e-commerce page, so of course, we have several market outlets for the same product. But if a company focuses a lot or is very strong in the Horeca channel, then in times of COVID it will have a terrible time". 
Table A2. Cont.

\section{COMPANY 10}

Department manager: "We have been affected by the coronavirus, especially in terms of visiting our clients. In the end, our sales method in vegetable production is mostly commercial visits to clients". "[ ... ] in April, which is when visits are made to close deals with clients, in the end, up to 70 or $80 \%$ of the visits have been lost".

Department manager: "The most important campaign for us has passed, which is the tomato campaign and also the corn campaign; in April, which is when the visits are made to close the deal with the clients; in the end, up to 70 or $80 \%$ of the visits have been lost".

Department manager: "In addition, in the agricultural sector, what we are doing now, that is, meeting someone in a video-conference, is very difficult, but we try".

Department manager: "In the same way, in the area of animal production, sales have also dropped a lot. They also have the crisis of the Iberian pig".

\section{COMPANY 11}

CEO: "Before the pandemic, we had an investment and development budget of approximately 1,000,000 $€$ intangible assets and we had an investment and development protocol to invest 500,000 $€$ in research and development every year. In fact, in 2019 we invested 800,000 $€$, which was an exceptional investment year. And this year, the pandemic has forced us to cut that budget because the benefits have dropped".

CEO: "Right now with the consumer crisis that we have in Spain, relatively speaking, we are doing a little better. We sell a lot abroad. Now, two of our main markets, England and France, are also hit by the pandemic and although the consumption of Iberian products there has also decreased, it has not done so in the same way as in Spain. Bear in mind that our products are typical for meetings, celebrations, events, get-togethers and if they are not available, the situation becomes complicated".

CEO: "Now we are working a lot on online marketing because we think it is part of the future, especially now with the pandemic".

Operations Director: "COVID-19 has had a negative impact and has resulted in a drop in sales. Last year we had a turnover of about 18 million euros. At present the loss of turnover is about 3 million euros. In other words, we are going to have a $61 \%$ drop in our sales. And also where we are most noticing this drop in sales is in hams, which is the product that contributes volume and margin to the business".

Operations Director: "There is a drop in sales because the HORECA channel has collapsed, and because consumers, faced with fear of the situation of economic uncertainty, will always go to those products that have a lower value and perhaps have a position in the market is very similar, so they always affect the one with the highest value..." .

Operations Director: "In the current situation there is a drop in sales".

Director of operations: "[ ... ] When there is a crisis situation, like the one we find ourselves in now and the consumer is sensitive to price, the most affected sector will be precisely the one that opts for Iberian and traditional products".

\section{COMPANY 12}

Department manager: "COVID-19 has affected us positively and negatively. In the restaurant area, there has been a lull. Unfortunately, this has been the case and nothing else can be done. On the other hand, we have had an increase in sales in the other area, in filleting and processing. Because in the end, when people were at home, what they consumed were ready meals and they no longer went to restaurants. This has created a very strong demand, which, in fact, in March was a bit overwhelming, because we were waiting for another packing machine to arrive, which fortunately arrived on time because we had to double staff, lines ... So, all the staff that we had in the hospitality industry got on those lines to lend a hand since there was a lot of demand in that area. In the end, we were all the same, shopping in supermarkets and trying to spend as little time as possible there and people did not stop at the butchers, but preferred ready meals and, in the shortest possible time, to get back home".

Department manager: "In the part of Madrid we also have hospitality, although now with this situation, it is a bit in the doldrums". 
Table A2. Cont.

\section{COMPANY 13}

CEO: "It is difficult to determine because precisely this year has been disastrous because of the weather. We have only obtained $50 \%$ of the usual production [... I It has not affected us directly as it has happened to the hotel industry. Although we believe that we have not noticed it so much in the market due to the misfortune of the weather year that has reduced production by half. One wonders whether the markets would have acted the same if this fact had not happened".

CEO: "Perhaps where this situation has affected us the most has been at the level of costs at the plant. We have had to invest a lot of money to adapt and implement action protocols for our workers. Take into account that in the campaign, we can reach 1000 workers and in this situation of health risk we have had to provide many material means such as hydroalcoholic gels, masks, changes of tables in the dining rooms, new temperature controls, spacing the entrance areas of the plant. For example, before we had 5 lines and the workers were entering at the same time. Now according to our protocols, each line has to enter half an hour after from the previous one". This is fine to ensure safety, but it is also causing us to reduce production, because we are delaying it. Therefore, it has been noticed more at the cost and investment level to adapt our plant than at the market level".

CEO: "With the situation of the pandemic, Zoom has made it much easier. For example, now we are going to hold a meeting of the Board of all the Governing Boards online. This will allow the rest of the cooperatives to know what the end of the campaign report is and we will allow all the members to connect and not just the administrator of each of the 15 cooperatives as happened before".

CEO: "[ . . . ] in berries, we have currants. We have very little of this product. It is very oriented to consume it and use it in desserts; We have had a client who sold it directly to the hospitality industry and this year they have not sold anything".

\section{COMPANY 14}

CEO: "From an operational point of view, for the moment, being a company that produces basic necessities, lockdown has not affected us because our campaign in Extremadura runs from the beginning of June to the end of March. During March, April and May we stopped and dedicated ourselves to making projects, modifying lines, doing maintenance ... among other things; As the confinement began in March, we were caught when fewer people were working in the company since the campaigns had ended. Therefore, we never stop producing".

CEO: "In our plant we have had only one positive case and we have protocols that ensure the safety all our workers. With the positive person in coronavirus we acted fast. In fact, and using the services of an external company, we carried out up to 48 PCRs on all staff members who could have been in contact with that worker [...] In short, as soon as the state of alarm was decreed here, the protocol crisis was activated and implemented right from the beginning".

CEO: "Other actions we carried out were to reduce capacity and provide protective equipment to all our employees".

CEO: "In the HORECA channel, sales have fallen by 17\%, because the school canteens closed, the restaurants... So we thought that the gains in retail were going to offset these losses, but it has not been like that. Yes, it is true that part of it has been compensated, but taking into account the situation of many citizens, some are in ERTE, others without work, people are afraid and that leads to a decline in consumption".

\section{COMPANY 15}

CEO: "In principle, we almost benefited from the coronavirus situation since in part the demand for our products is shifting. For example, we have 3 product lines: fresh garlic, peeled garlic clove and garlic paste. In the case of the peeled garlic clove, the final consumer does not use it because it is aimed at the hospitality and industry, and the hospitality industry has closed, so its consumption decreased. It is also true that if consumption in the hospitality industry decreases, household consumption increases, although not in the same proportion, but now the demand for fresh garlic has grown and that of peeled cloves has decreased".

CEO: "We made a significant investment in the machinery to produce our garlic cloves. However, on reducing the demand for this product because it has shifted towards fresh garlic, it means we are not getting the expected performance, therefore, this is an inconvenience".

CEO: "We also have to say that prices have remained high and demand has increased for our product, dried whole garlic. So in general we can say that it has almost benefited us". 
Table A2. Cont.

\section{COMPANY 15}

CEO: "Digitization is being encouraged. We continue working through WhatsApp, which is a very useful tool for making video calls, sending photos ... also, everyone knows it and uses it".

\section{TECHNOLOGICAL CENTER}

CEO: "I think that the Administration in this situation of COVID-19, is showing the least capacity for reaction".

CEO: "We made an emergency action plan. The coronavirus has not interrupted us at all, but we have provided the same services. We started services that are independent from the Administration, which is a big bottleneck".

CEO: "Precisely one of the things that we did and that has allowed us to differentiate ourselves from our competitors was to put forward all our public projects and to implement an action plan for high-value services that are independent of financing by public entities, because we knew that everything was stopping".

CEO: "Of course, all this has involved a great effort on the part of the entire team."

CEO: "A celebration is going to be held at our facilities and we are going to put up a tent, as we need more space due to the coronavirus situation. We are going to hold a public event to expose this and gain visibility".

CEO:"The coronavirus has also obliged us to get used to this type of meeting and that is in part an organizational change that has come to stay".

\section{Appendix C}

Table A3. Results of the 20 most frequent words.

\begin{tabular}{ccc}
\hline Word & Repetition/Frequency & Number of Letters \\
\hline Company & 59 & 7 \\
COVID-19 & 25 & 8 \\
Coronavirus & 25 & 11 \\
Affected & 13 & 8 \\
Sales & 12 & 5 \\
Market & 8 & 6 \\
Customers & 8 & 9 \\
Sector & 8 & 6 \\
Hostelry & 8 & 9 \\
Production & 7 & 10 \\
Consumption & 7 & 10 \\
Demand & 7 & 6 \\
Online & 6 & 6 \\
Trend & 6 & 5 \\
Actions & 6 & $7-$ \\
Development & 6 & 11 \\
Crisis & 5 & 6 \\
Prices & 5 & 6 \\
Drop & 5 & 4 \\
Protocols & 5 & 9 \\
\hline
\end{tabular}




\section{Appendix D}

Table A4. Summary of the results.

\begin{tabular}{l}
\hline Negative Impacts \\
\hline $\begin{array}{l}\text { Decrease in sales and turnover in the Horeca channel, high-value products and celebration } \\
\text { products. }\end{array}$ \\
\hline $\begin{array}{l}\text { Displacement in the demand for products towards household consumer products and } \\
\text { lower-priced substitute products. }\end{array}$ \\
\hline $\begin{array}{l}\text { Difficulty in marketing activities; temporary stoppage of promotion, marketing and attendance at } \\
\text { fairs and events. }\end{array}$ \\
\hline Slowdown and budget reduction in R\&D projects \\
\hline Lack of staff (quarantine) \\
\hline Stoppage or decrease in some company activities \\
\hline Supply problems \\
\hline Positive Impacts \\
\hline Increase in production and sales in certain activities \\
\hline Actions carried out by the companies \\
\hline Search and diversification of clients and suppliers in other markets \\
\hline Increased use of technology in communication and marketing activities \\
\hline Reorganization of personnel and activities \\
\hline Implementation of new health protocols \\
\hline Development of new products \\
\hline
\end{tabular}

\section{References}

1. Gjaja, M.; Faeste, L.; Hansell, G.; Hohner, D. COVID 19: Win the Fight, Win the Future. 2020. Available online: https: / / www.bcg.com/publications/2020/covid-scenario-planning-winning-the-future-series (accessed on 11 January 2021).

2. CaixaBank Research. Informe Sectorial Agroalimentario 2020. Resiliencia y Desarrollo del Sector Durante la Pandemia, 2020. Available online: https:/ / www.caixabankresearch.com/es/informes-sectoriales/octubre-2020/agroalimentario (accessed on 11 December 2020).

3. FIAB. Informe Económico 2019. Spanish Federation of Food and Beverage Industries, 2020. Available online: https://fiab.es/es/ archivos/documentos/INFECO_2019.pdf (accessed on 20 December 2020).

4. Bank of Spain. Evolución Reciente y Perspectivas Para el Sector Turístico Español e Implicaciones Para el Conjunto de la Economía; Informe Annual: 2019. Available online: https:/ / repositorio.bde.es/bitstream/123456789/13053/1/InfAnual_2019-Rec4.1.pdf (accessed on 11 April 2021).

5. State Tax Administration Agency (AEAT). Estadísticas de Comercio Exterior. Principales resultados. 2020. Available online: https: / / www.agenciatributaria.es/AEAT.internet/datosabiertos/catalogo/hacienda/comercio_exterior/datos_estadisticos / principales_resultados.shtml (accessed on 11 April 2021).

6. National Institute of Statistics (NSI). Population Figures. Available online: https://www.ine.es/jaxiT3/Datos.htm?t=9681 (accessed on 10 April 2021).

7. National Institute of Statistics (NSI). Central Business Directory. Available online: https://www.ine.es/jaxiT3/Datos.htm?t=39372 (accessed on 11 April 2021).

8. Grupo Alba Internacional. Contexto de la Comunidad Autónoma de Extremadura; Programa de Desarrollo Rural 20142020; Grupo Alba Internacional: 2014. Available online: http://www.juntaex.es//filescms/ddgg002/uploaded_files/fondos_ europeos/FondosEuropeos2014_2020/BORRADOR_CONTEXTO_EXTREMADURA_FEADER_2014_2020.pdf (accessed on 11 April 2021).

9. Corchuelo, B.; Mesías, F.J. Disposición a innovar y competitividad en la agroindustria extremeña. Inf. Téc. Econ. Agrar. 2017, 113, 176-191.

10. Carrasco, M.; Chandran, P.; Chin, V.; Hayden, P.; Hoteit, L.; Subudhi, S.; Werfel, D. Strat Remaining Government Now: Beyond the Curve, 2020. Available online: https:/ / www.bcg.com/publications/2020/start-reimagining-government-now (accessed on 27 November 2020). 
11. BDO. COVID-19 Is Accelerating the Rise of the Digital Economy. Digital Transformation in the Pandemic and Post-Pandemic Era. Available online: https://www.bdo.com/insights/business-financial-advisory/strategy,-technology-transformation/covid19-is-accelerating-the-rise-of-the-digital-e (accessed on 28 April 2021).

12. UNCTAD. COVID-19 and e-Commerce. A Global Review; United Nations Conference on Trade and Development: 2021. Available online: https://unctad.org/es/node/32378 (accessed on 11 April 2021).

13. Tarcisio, D.M.; Allison, C. Rethinking tax for the digital economy after COVID-19. HBLR 2021. [CrossRef]

14. Grigorescu, A.; Pelinescu, A.; Ion, A.E.; Dutcas, M.F. Human capital in digital economy: An empirical analysis of central and eastern European countries from the European Union. Sustainability 2021, 13, 2020. [CrossRef]

15. Sigala, M. Tourism and COVID-19: Impacts and implications for advancing and resetting industry and research. J. Bus. Res. 2020, 117, 312-321. [CrossRef] [PubMed]

16. Makhiboroda, M.; Ananyeva, E.; Doucek, P. Changes in transport activity regulation in the context of the coronavirus pandemic. In E3S Web of Conferences (Vol. 222). EDP Sci. 2020. [CrossRef]

17. OECD. The Territorial Impact of COVID-19: Managing the Crisis across Levels of Government; Organization for Economic Cooperation and Development: 2020. Available online: https://www.oecd.org/coronavirus/policy-responses/theterritorialimpact-of-covid-19-managing-the-crisis-across-levels-ofgovernment-d3e314e1/ (accessed on 11 April 2021).

18. Lazarus, J.V.; Ratzan, S.; Palayew, A.; Billari, F.B.; Binagwaho, A.; Kimball, S.; Larson, H.; Melegaro, A.; Rabin, K.; White, T.M.; et al. COVID-SCORE: A global survey to assess public perceptions of government responses to COVID-19 (COVID-SCORE-10). PLoS ONE 2020. [CrossRef] [PubMed]

19. Bol, D.; Giani, M.; Blais, A.; Loewen, P.J. The effect of COVID-19 lockdowns on political support: Some good news for democracy? Eur. J. Political Res. 2021, 60, 497-505. [CrossRef]

20. Al-Hasn, A.; Yim, D.; Khunti, J. Citizens' adherence to COVID-19 mitigation recommendations by the government: A 3-country comparative evaluation using web-based cross-sectional survey data. J. Med. Internet Res. 2020, 22, e20634. [CrossRef] [PubMed]

21. Roos, A.; Satange, S.; Tucker, J.; Grabowski, J.; Uebber, B. COVID-19 CFO Pulse Check 2. 2020. Available online: https: / / www.bcg.com/publications/2020/ covid-cfo-pulse-check-2 (accessed on 27 November 2020).

22. Carlsson-Szlezak, P.; Swartz, P.; Reeves, M. Why the global economy is recovery faster than expected? 2020. Available online: https:/ / hbr.org/2020/11/why-the-global-economy-is-recovering-faster-than-expected (accessed on 27 November 2020).

23. Bharadwaj, A.; Sanghi, K.; Witschi, P.; Balaji, N.; Chen, C. Edition 3: Who Is the Emerging-Market Consumer in the Post Pandemic Era? 2020. Available online: https:/ / www.bcg.com/publications/2020/covid-19-impact-emerging-market-consumers-thirdedition (accessed on 27 November 2020).

24. Russo, M.; Feng, T. Contact Tracing Accelerates a Lot of Opportunities and Risks: The Economy of IoT Data Sharing. 2020. Available online: https:/ /www.bcg.com/publications/2020/contact-tracing-accelerates-iot-opportunities-and-risks-2 (accessed on 27 November 2020).

25. Chan, T.; Lang, N.; Modi, S.; Tang, T.; von Szcepanski, K. How Chinese Digital Ecosystem Battle COVID 19. 2020. Available online: https:/ / www.bcg.com/publications/2020/how-chinese-digital-ecosystems-battled-covid-19 (accessed on 27 November 2020).

26. Kropp, M.; Andersen, P. How to Price-and-Sell in a Pandemic. 2020. Available online: https://www.bcg.com/capabilities/ marketing-sales/best-practices-for-sales-managers-covid-19 (accessed on 27 November 2020).

27. McKinsey \& Company. COVID-19 and the Great Reset: Briefing Note \#31, November 2020. Available online: https:/ /www.mckinsey. de/business-functions/risk/our-insights / covid-19-implications-for-business (accessed on 27 November 2020).

28. Bona, C.; Koslow, L.; Frantz, R.; Nadres, B.; Ratacjczak, D. How Marketers Can Win with the Gen Z and Millenials Post-COVID. 2020. Available online: https:/ / www.bcg.com/publications/2020/how-marketers-can-win-with-gen-z-millennials-post-covid (accessed on 27 November 2020).

29. Lesser, R.; Reeves, M. Leading out Adversity. 2020. Available online: https://www.bcg.com/publications/2020/businessresilience-lessons-covid-19 (accessed on 27 November 2020).

30. Barcaccia, G.; D'Agostino, V.; Zotti, A.; Cozzi, B. Impact of the SARS-CoV-2 on the Italian Agri-food Sector: An Analysis of the Quarter of Pandemic Lockdown and Clues for a Socio-Economic and Territorial Restart. Sustainability 2020, 12, 5651. [CrossRef]

31. Hossain, S.T. Impacts of COVID-19 on the agri-food sector: Food security policies of asian productivity organization members. J. Agric. Sci. 2020, 15, 116-132. [CrossRef]

32. Patterson, G.T.; Thomas, L.F.; Coyne, L.A.; Rushton, J. Moving health to the heart of agri-food policies; mitigating risk from our food systems. Glob. Food Sec. 2020, 26, 100424. [CrossRef] [PubMed]

33. UNIDO. Agri-Food and COVID-19 in Egypt: Adaptation, Recovery and Transformation; United Nations Industrial Development organization: 2020. Available online: https://www.unido.org/sites/default/files/files/2020-09/IGGE_Agrifood_and_COVID19. pdf (accessed on 17 April 2021).

34. FAO. Adjusting Business Models to Sustain Agri-Food Enterprises during COVID-19. 2020. Rome. Available online: https: / / doi.org/10.4060/ca8996en (accessed on 12 December 2020).

35. Stephens, E.C.; Martin, G.; van Wijk, M.; Timsina, J.; Snow, V. Impacts of COVID-19 on Agricultural and food systems worldwide and on progress to the sustainable development goals. Agric. Syst. 2020, 183, 102873. [CrossRef] [PubMed]

36. Torero, M. Without food, there can be no exit from the pandemic. Countries must join forces to avert a global food crisis from COVID-19. Nature 2020, 580, 588-589. [CrossRef] [PubMed] 
37. Mukhamedjanova, K. The impact of the Covid-19 pandemic on the supply chain of agricultural products. Asian J. Technol. Manag. Res. 2020, 10, 49-52.

38. Caldart, A.; Gifra, J.; Akhmedova, A.; La Crisis de la COVID-19 en el Sector de Alimentación y Bebidas. Impacto y Futuro. 2021. IESE Business School. University of Navarra 2021, 17. Available online: https://media.iese.edu/research/pdfs/ST-0608 (accessed on 10 April 2021).

39. FIAB. Impacto de la Crisis del COVID-19 en la Industria de Alimentación y Bebidas Española; Spanish Federation of Food and Beverage Industries: 2020. Available online: https: / fiab.es/producto/impacto-covid-19-industria-alimentacion-y-bebidas / (accessed on 11 April 2021).

40. Ruiz, J.I. Metodología de la Investigación Cualitativa, 4th ed.; Universidad Deusto: Bilbao, Spain, 2007.

41. Yin, R.K. Case Study Research: Design and Methods (Applied Social Research Methods); Sage: Newbury Park, CA, USA, 1989.

42. Tell, J.; Hoveskog, M.; Ulvenblad, P.; Ulvenblad, P.-O.; Barth, H.; Ståhl, J. Business model innovation in the agri-food sector: A literature review. Brit. Food J. 2016, 118, 1462-1476. [CrossRef]

43. MAPA. Informe del consumo alimentario en España 2018; Ministerio de Agricultura, Pesca y Alimentación: 2019. Available online: https:/ / www.mapa.gob.es/images/es/20190807_informedeconsumo2018pdf_tcm30-512256.pdf (accessed on 10 April 2021).

44. EIT Food. Impact of COVID-19 on the Food Sector in Southern Europe. Madrid. 2020. Available online: https://www.eitfood.eu/ projects / food-foresight (accessed on 10 January 2021).

45. Zhang, Y.; Diao, X.; Chen, K.Z.; Robinson, S.; Fan, S. Impact of COVID-19 on China's macroeconomy and agri-food system-An economy-wide multiplier model analysis. China Agric. Econ. Rev. 2020, 12, 387-407. [CrossRef]

46. United Nations. Sustainable Development Goals. United Nations. 2019. Available online: https://sdgs.un.org/goals (accessed on 17 April 2021). 